\title{
Development of Wireless Sensor Network for Monitoring Air Temperature and Soil Moisture on Crops
}

\begin{abstract}
Wulandari
Abstract - Crops including the types of plants that can be grown in dry areas. In dry areas as development land crops, humans attempt to make this by doing irrigation. However, if the amount of water given too much will cause the plants rot and crop failures. Therefore, necessary irrigation system that can be monitored periodically by the farmers to avoid such problems. Wireless sensor networks can be used to monitor land crops. By using the temperature and humidity sensors and soil moisture sensors, soil will be monitored regularly every hour. Data resulting from sensor readings are sent to the database using the GPRS network. The results showed that the prototype of a wireless sensor network on crops have been successfully developed.
\end{abstract}

Keywords—GPRS, Humidity, Microcontroller, Sensor, Temperature.

\section{INTRODUCTION}

$\mathrm{I}^{\mathrm{n}}$ recent years, soybeans became national conversation because it includes one of the commodities imported at a cost of trillions of dollars. It is caused by a decline in soybean production to keep pace with the high demand of soybean. According to the Central Statistics Agency (BPS) national soybean production in 2012 reached about 850,000 tons. However, the domestic soybean demand estimated 2.4 million tons (source: www.antaranews.com). To help improve the productivity of soybean plants, need to pay more attention to the process of planting and plant care including watering plants in the event.

Watering plants is often done with a dose based on intuition, experience and knowledge is passed down from generation to generation. In fact provision of water in plants effectively and efficiently in accordance with the needs of plants and soil conditions are important factors for the growth and yield (source: http://cybex.deptan.go.id).

Of course this will be more complex if the plants require specific care and intensive crops like soybeans. Soybean plants are not resistant to drought or waterlogging. For the irrigation and drainage needs to be done to maintain the state of the water content in the soil at field capacity, which is kept moist but not wet (source: http://cybex.deptan.go.id). Provision of adequate water for growth will increase soybean yield, quality and quantity.

Interaction between temperature-intensity solar radiation-soil moisture is crucial growth rate of soybean plants. High temperatures associated with high transpiration, water vapor deficit of high voltage, and drought stress in plants. In soil temperature and atmospheric temperature affect rhyzobium, roots and soybean crops. Appropriate temperature for the growth of soybean plants ranges between $22-27^{\circ} \mathrm{C}$ (Sumarno and Mansuri, 2007).

These problems can be solved with solutions such as a wireless sensor network that can monitor the temperature

${ }^{1}$ Wulandari is with Departement of Computer Sciences, Faculty of Mathematics and Natural Sciences, Institut Pertanian Bogor, Bogor, Indonesia. E-mail: wulandari.ilkom@apps.ipb.ac.id. and humidity of the environment as well as the moisture from the ground by using the sensor. The readings from the sensors sent to a website that will be the base of data from two wireless sensor nodes. Temperature and humidity data from an input of fuzzy logic are used to obtain the required length of time watering by soybean plants. Fuzzy logic is the method of Tsukamoto.

\section{METHODS}

\section{A. Planning Phase}

At this stage of the planning of the system are made. System design can be seen in Figure 1.

\section{B. Analysis Phase}

The process of system analysis aims to determine the need for the system to be built. Analysis is conducted needs analysis of required data to build fuzzy logic and agricultural monitoring tool. Monitoring systems in this study is using GPRS to send data remotely. GPRS systems have a wider range of signals follow a particular provider of GSM signal in a region and only require internet package costs.

\section{Designing Phase}

At the design stage is composed of a variety of jobs.

1) The design of the system architecture

This stage aims to determine the form of the communication system to be built.

2) The design of data communication

This stage aims to determine the type of data communications. Communication used between GPRS Shield, temperature sensor, soil moisture sensor with the Arduino using serial communication.

3) The design of the system flow

This design aims to provide an overview of data flow and data retrieval of data transmission via GPRS communication.

4) The design of the data base

Database design aims to determine the required of tables in the data base.

\section{Implementation Phase}

At this stage, the fuzzy logic algorithm has been developed to be implemented on the Arduino. 


\section{E. Testing Phase}

This stage of testing the functionality of the system, if desired functions and specifications have not been achieved, it will be repaired.

\section{RESULT AND DISCUSSION}

Humidity sensors connected to the Arduino using the analog port 3 and a temperature sensor connected to the Arduino connected via analog port 0 . At this stage the Arduino has successfully connected with humidity sensor and temperature sensor. Besides fuzzification has been successfully implemented. Each input and output variables have linguistic values can be seen in Table 1 .

This fuzzification produce rules that are used in this system are can be seen at Table 2. This system also has managed to send information to a database of Arduino.

\section{CONCLUSION}

Wireless sensor network systems and the development of decision-making for a amount of watering time with
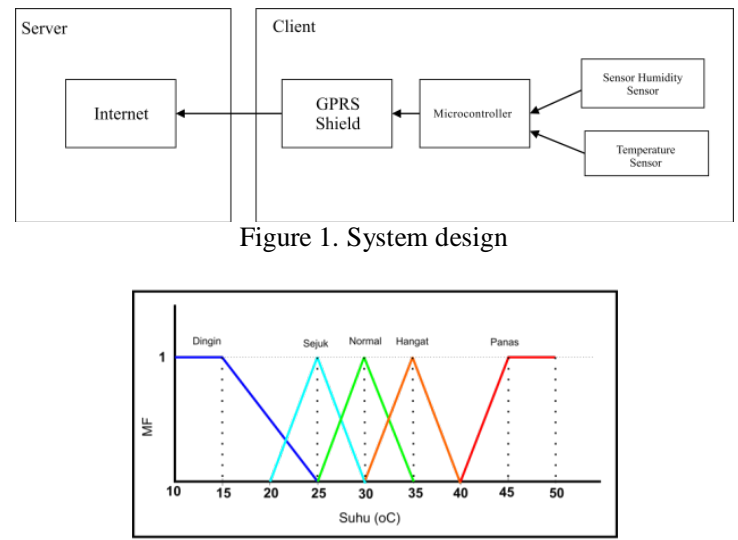

Figure 2. Temperature fuzzy parameter

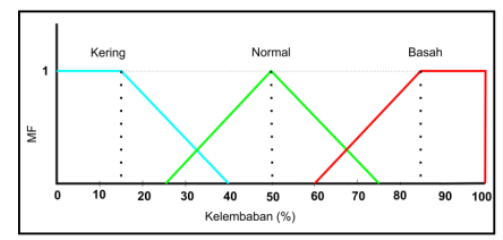

Figure 3. Moisture fuzzy parameter

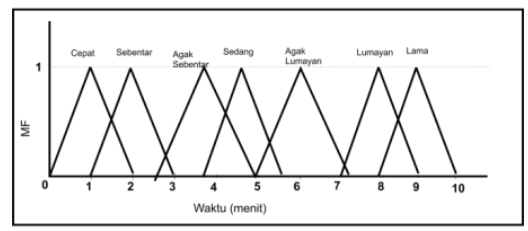

Figure 4. Watering time fuzzy parameter

\section{C $\square$ www.e-slb.com/awp/read_data1.php}

Tanaman 1

\begin{tabular}{|c|c|c|c|}
\hline Waktu & Kelembaban & Suhu & Waktu siram (detik) \\
\hline |2012-07-22 10:41:00|| & 40 & |33 & 76 \\
\hline 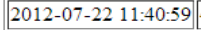 & 40 & 34 & 75 \\
\hline $2012-07-22$ 12:40:57 & 39 & 40 & 72 \\
\hline $\mid 2012-07-22$ 13:41:00| & 39 & 34 & 75 \\
\hline
\end{tabular}

fuzzy logic can be formed even though the actuator system still not done yet.

\section{REFERENCES}

[1]. Pikiran Rakyat Online. 2012. “ Pertanian Indonesia Tidak Ditata Dengan Baik“. From : http://www.pikiranrakyat.com/node/198918, 22 Oktober 2012

[2]. Putrie, F. 2013. “ Tataniaga Kedelai Untuk Kepastian Harga Petani”. From “ www.antaranews.com/berita/378668/tataniagakedelai-untuk-kepastian-harga-petani, 15 Juni 2013.

[3]. Rochiyat. 2013. Rancang Bangun Monitoring Sistem Irigasi Otomatis Berbasis Gsm/GPRS. IPB:Bogor

[4]. Sofwan, A. 2005. "Penerapan Fuzzy Logic pada Sistem Pengaturan Jumlah Air Berdasarkan Suhu dan Kelembapan”. Electrical Engineering Department. Faculty of Industrial Technology. National Institute of Science and Technology.Stelee, James. (2007). The Android Depelover Cook's Book. Developer's Library. Boston:Pearson Education, Inc.

[5]. Yulia, TS. "Pemeliharaan Tanaman Kedelai". From cybex.deptan.go.id/penyuluhan /pemeliharaan-tanaman-kedelai, 15 Juni 2013.

TABLE 1.

LINGUISTIC VALUES OF FUZZY SYSTEM

\begin{tabular}{|c|c|c|c|}
\hline & Variabel & Parameter & Nilai linguistik \\
\hline \multirow{7}{*}{ Input } & \multirow{5}{*}{ Suhu udara } & Dingin & $10^{\circ} \mathrm{C}-25^{\circ} \mathrm{C}$ \\
\hline & & Sejuk & $20^{\circ} \mathrm{C}-30^{\circ} \mathrm{C}$ \\
\hline & & Normal & $25^{\circ} \mathrm{C}-35^{\circ} \mathrm{C}$ \\
\hline & & Hangat & $30^{\circ} \mathrm{C}-40^{\circ} \mathrm{C}$ \\
\hline & & Panas & $35^{\circ} \mathrm{C}-50^{\circ} \mathrm{C}$ \\
\hline & \multirow{6}{*}{ Kelembaban } & Kering & $0 \%-40 \%$ \\
\hline & & Normal & $25 \%-75 \%$ \\
\hline \multirow{8}{*}{ Output } & & Basah & $50 \%-100 \%$ \\
\hline & & Cepat & 0 - 2 menit \\
\hline & & Sebentar & 1 - 3 menit \\
\hline & & Agak Sebentar & 2.5 - 5 menit \\
\hline & \multirow[t]{4}{*}{ Lama penyiraman } & Sedang & 3.75 - 6.25 menit \\
\hline & & Agak Lumayan & 5 - 7.5 menit \\
\hline & & Lumayan & 7 - 9 menit \\
\hline & & Lama & 8 - 10 menit \\
\hline
\end{tabular}


TABLE 2.

RULES OF FUZZY SYSTEM

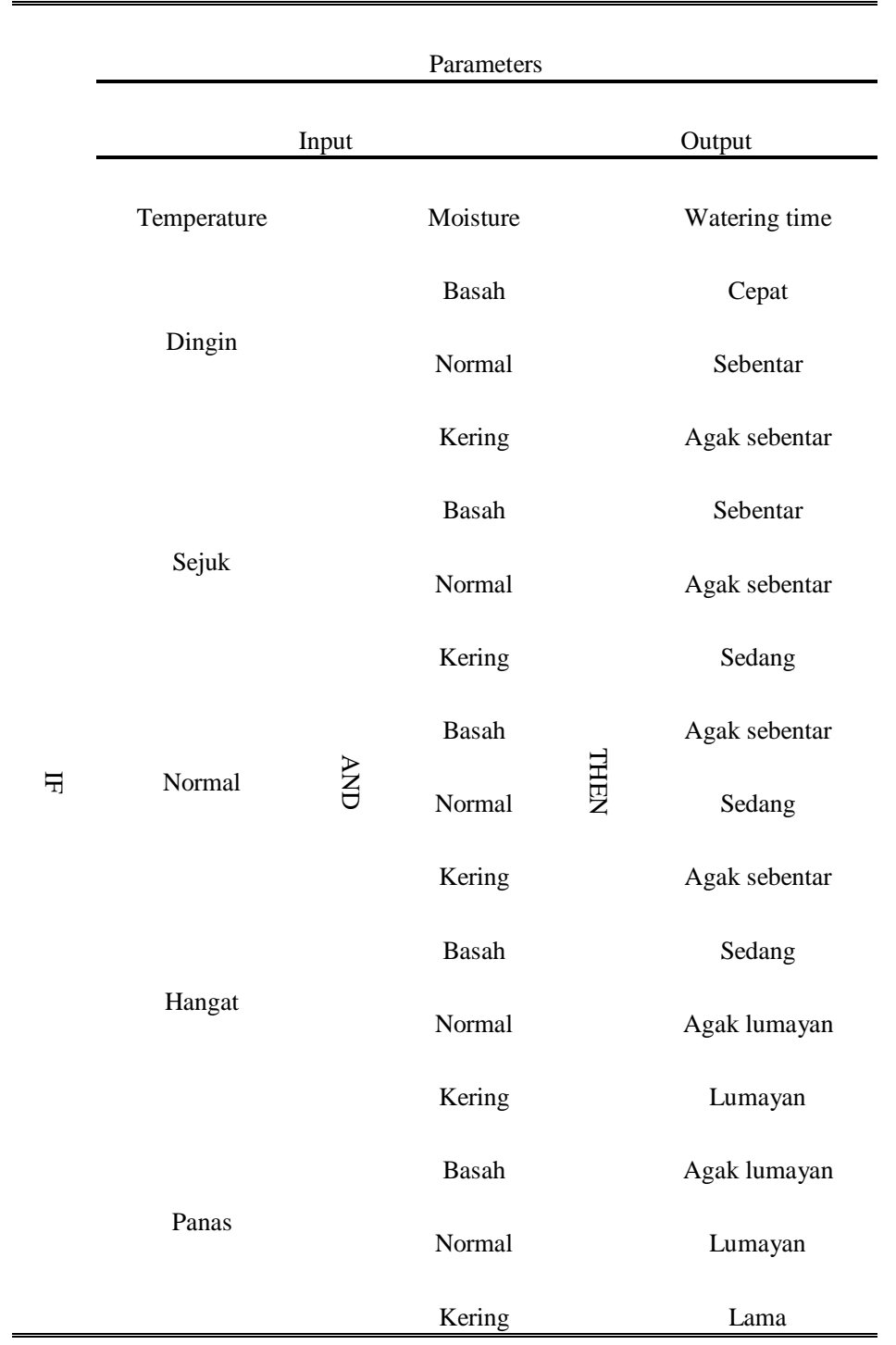

